\title{
Prosecution in Criminal Tax Proceeding in Nigeria, Legal Challenges
}

\author{
Rita Dashe Selkur*
}

\begin{abstract}
:
Tax, being a compulsory exertion by government on the citizen, is regulated by statute in which case citizens are to comply with. It is a strict liability offence which if it is demanded that you have not paid, the defence is for you to show you have paid. Be it an individual or corporate body.

The concept of prosecution in Taxation in Nigeria is roughly captured by the FIRS ACT for the Federal government and the SIRB Law for the various States, including the TAT ACTS as an undertaking in the progressive development and reform of the substantive and applicable laws in Nigeria to be on the same page with the developed countries.

Where there is an offence, the law proscribes for penalty which could be in terms of fines, imprisonment etc. However, some of these offences are sometimes not prosecuted. It is recommended that in order to ensure tax compliance, prosecution of offences should be taken seriously as the outcome of any tax matter affects the behaviour of tax payers wherein, it is taken that the motivation for crime is the criminal's belief that he can enjoy his loot.

I have highlighted the importance and the process in prosecution of Tax offences, the worrying aspect in my humble view in form of the challenges which needs to be considered critically then finally, a pause to rethink and the way forward. Useful materials were gotten from books, journals and the internet.
\end{abstract}

\section{INTRODUCTION:}

Tax offence - a serious act of sabotage is an impediment to the growth of the Nigerian society as useful revenue will be constantly lost to Tax criminality on a daily basis. Though the Nigerian Tax system before now may not be the most important source of revenue to the government in terms of revenue derivable from taxation, as oil was the most dominant source of revenue from the point of view of certainty and consistency but with the depleting income from crude oil revenue in addition with rising populace, government has been compelled to go on an aggressive drive to generate revenue to meet high drives. Taxation thus is an important source of revenue to the government from time immemorial, owing to its inherent power to impose taxes, the government is assured at all times of its tax revenue, no matter the circumstances.

* Chief magistrate court Bokkos; ritataglory@gmail.com. 


\section{A. IMPORTANCE OF TAXATION IN NIGERIA}

Taxation is the process involved in the administration and collection of $\operatorname{tax}^{1}$ Taxation may either be an incentive or disincentive on the individual and the society to work or save. A tax with a high marginal rate of tax in excess of $50 \%$ is definitely a disincentive to work while a low marginal rate of tax may actually be an incentive to work. Government imposes taxes as a means to provide collective wants ${ }^{2}$ and a tool for government economic policies, like in any community or among a group of individuals for the running of the government, country or state purposes ${ }^{3}$.

There are a number of needs and services which are better and more economically provided collectively than individually, like defence, education, utilities, health services, sanitation and social amenities. Taxation being a tool for government economic policy, may be used by the government for the redistribution of wealth, to effect changes in the country's balance of payment with other countries to effect the mobilization of economic resources, to influence the desired level of economic activities in specific sectors and to combat inflation.

\section{B. TAX PROSECUTION}

The purpose of prosecution is to serve as deterrence, whereby a few are prosecuted to scare the many into staying honest. Where there is financial crime and a breach, the law will come in especially in corruption, tax avoidance and tax evasion. Absence of the fear of prosecution is likely to cause a large number of otherwise ordinary and likable citizens become criminals.

Prosecution is usually at the instance of the relevant tax authority who have powers to prosecute any of the offences under the Act, subject to the powers ${ }^{4}$ of the Attorney General of the State of the Federation. Tax payer investigation ${ }^{5}$, being an in depth investigation processed by a tax authority in order to recover tax undercharged in previous years, was introduced to deal with tax payers unwillingness to comply with the tax provisions or the tax payer scheming to circumvent the provision of the tax laws in order to reduce their liabilities either legally or illegally, therefore, it is a guard against out right tax evasion, specific area of non compliance, tax malpractices and negligence of tax fraud.

An inquiry into the tax affairs of an individual or a company will arise if existence of evasion is suspected. Such suspicion could arise from the review of the record of the tax payer which shows consistent under payment. Administration of taxation in Nigeria is ves-

1 Osita Aguolu: TAXATION and TAX MANAGEMENT In Nigeria; 2009 p3.

2 Ayua I.A: The Nigeria Tax Law;1996 p9.

3 Morse, G\& Williams, G. Davies: principles of Tax Law; 2004 p3.

4 Sections 211,174. 1999 constitution as ammended.

5 HTTPS://EN.WIKIPEDIA.ORG/WIKI/TAX investigation. accessed 1/5/2019. 
ted in certain authorities depending on the tax in question. There are three major tax authorities in Nigeria which are:

I. Federal Inland Revenue Service(FIRS). It was first established as an operational arm of the Federal Board of Inland Revenue (FBIR) in 1993 but became autonomous in 2007 and was saddled with the responsibility of controlling and administering different taxes as well as accounting for all taxes collected.

II. State Internal Revenue Service

III. Local Government Revenue Committee.

\section{RELEVANT TAX AUTHORITY}

A Relevant Tax Authority ${ }^{6}$ is the tax authority which has the jurisdiction to collect tax. In Nigeria, it is either the Federal Inland Revenue Service Board, or the State Board of Inland Revenue and the Local Government Revenue Committee. In a Federal County like Nigeria, the importance of having a coherent tax system need not be stressed it is indeed desirable that the taxing powers of the different and independent layers of government should be consistent with each other for if they clash this could be disastrous from the stand point of their effects on incentives which, if adverse are bound to cause distortion in the national economy.

A good system ${ }^{7}$ should be simple and straight forward above all, for the required revenue to be realised there must be an efficient tax administration where everybody will be fairly and duly assessed, but not oppressed. Tax jurisdictions are derivatives of legislative powers set out in the constitution, with the prescribed list of taxes giving dominance to the federal government over the most important and most beneficial areas of the economy ${ }^{8}$. It is in the light of the above that it has become so pertinent for the relevant tax authority to know its scope ${ }^{9}$ and what kinds of tax it's in charge of.

\section{FEDERAL GOVERNMENT}

1. Import Duties.

2. Export Duties.

3. Excise Duties.

4. Mining Rents and Royalties.

5. Petroleum Profit Tax.

6. Companies Income Tax.

6 Ola, C.S: Income Tax Law and practice in Nigeria; 2004 p8.

7 Stephen Ocheni: principles and Practice of TAXATION IN NIGERIA. 2010 p3.

8 Sanni, A. S.(1998) " the approved list of Taxes: A commentary". Modern practice journal of finance and investment law 2(2).

9 Ola c.s op cit. 
7. Capital Gains Tax.

8. Personal Income Tax.

9. Personal Income Tax, Armed Forces.

10. External Affairs officers and Federal Capital Territory.

11 .Sales and Purchase Tax.

12 .Stamp Duties.

\section{STATE GOVERNMENT}

1. Purchase Taxes.

2. Football pools and other betting Taxes.

3. Estate Duties.

4. Gift Tax.

5. Land Tax other than Agricultural land.

6. Land Registration.

7. Capital gains Tax.

8. Companies Tax.

9. Stamp Duties (administration and Retention).

10. Land Registration (administration and Retention).

11. Licence fees on TV and Radio (administration and Retention).

\section{LOCAL GOVERNMET}

1. Property Tax.

2. Marketing and Trading licence fees.

3. Motor Park Dues.

4. Entertainment Tax Motor Vehicles Tax and Drivers licence fees.

The FIRS is empowered under section $35^{10}$ to

I. Employ special purpose Tax officers to assist any relevant law enforcement agency in the investigation of any offence under the Act.

II. Cause investigation to be conducted into the properties of any taxable person if it appears to the service that the lifestyle of the person and extent of the properties are not justified by his service of income.

III. Cause investigation to be conducted to ascertain any violation of any tax law whether or not such violation has been reported to the service.

1. The object of the service is to control and administer the different taxes and laws specified in the first schedule or other laws made or to be made, from time to 
time, by the National or state assembly or other regulations made thereunder by the Government of the Federation and to account for all taxes collected ${ }^{11}$.

2. By Section 8 of the FIRSEA, the Revenue Service is to assess persons, including companies, enterprises, chargeable with tax, including the provisions; from (b) to (h), by a warrant enter into premises and search, seize and take possession of any book, document or an article used or suspected to have been used in the commission of an offence.

An investigation of a criminal tax fraud or evasion can be terminated at any stage if

I. There is insufficient evidence,

II. Where it is discovered that there is no criminal intention, and it was merely a tax avoidance scheme where neither fraud nor evasion was involved.

III. Where the investigation has become statute barred it means that the tax provisions can no longer support the investigation which has been going on for so long that it appears no serious conclusions can be reached without a reasonable period.

Failure to pay tax attracts criminal penalty. Accordingly, an action may be pursued against any person or corporation to recover the tax. Tax prosecution usually takes place in the tribunal or the regular court initiated by the Relevant Tax authorities.

\section{TAXING STATUTES}

Tax laws in Nigeria are complex and difficult for the common tax payer to understand, and some cases are problematic even for literate officials. This being the case, many tax payers lack understanding and are unaware of the existence of certain taxes not forgetting the laziness of the tax officials, uncooperative taxpayers all these culminates in the manifestation of the poor tax education and weak fulfilment by tax authorities of their responsibilities with regard to public awareness.

I. Certain general principles formulated by the English courts to determine the true meaning and effect of the particular statutory provision ${ }^{12}$ were adopted by the Nigerian courts also to aid as a guide. A tax must be expressly imposed upon the subject by the clear word of the statute. The cardinal principle of taxation is that tax should not be imposed on a person unless the clear words of the taxing statutes expressly do so. In essence, a tax cannot be imposed on a subject without words in an Act clearly showing an intention to lay the burden on him. In Tennant V Smith ${ }^{13}$, Lord Hals bury, Lord Chancellor stated that in construing a taxing statute, you must see whether a tax is expressly imposed.

11 S. 2 FIRSEA 2007.

12 Olateju Abiola Somorin Teju Reference Book. Nigerian Tax System General Accounting Taxation Terms. P 2107.

13 (1892)(A.C 150.8 t.l.r 4343 TC 158). 
II. The words of the Acts must be given their ordinary or natural meaning no matter how unjust or unreasonable their meanings may appear to be. This principle is referred to as the Literal Rule of Interpretation. The basic function of the courts in interpreting the taxing statutes is to ascertain the ordinary or natural meaning of the words used in the taxing statute. Thus, Justice Kutigi JSC in AG Ondo State v AG Ekiti State ${ }^{14}$ and justice Niki Tobi in SPDC (Nig) Ltd v FBIR ${ }^{15}$ both held that if the words of the statute are plain, precise and unambiguous, they should be given their ordinary and natural meaning. Effect must be given to them without resorting to any aid internal or external.

The court is to also ensure that the true income of any taxable person is ascertain by preventing artificial devices to conceal the real income or reduce tax liability through ascribing appropriate meanings to the words used otherwise no revenue would be collected.

III. Liability to tax arises from the taxing statutes or Acts according to their true meaning and effect and not from any extraneous principles. The imposition of tax is a statutory matter and there is no common law of taxation.

IV. The court should not support any general principle underlying taxing statutes and remaining unexpressed. According to J.Rowlatt in Cape Brandy Syndicates V

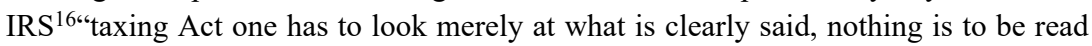
in, nothing is to be implied.One can only look fairly at the languages used"

V. Words are to be their natural meaning even if such a meaning encourages or validates tax avoidance IRC V Wolfson ${ }^{17}$

VI. Where there is ambiguity, the taxing statute should be construed in favour of the tax payer. This principle is known as the Golden Rule. J Rowlatt put it succinctly as follows 'in revenue matters, there is no room for intendment. Ambiguity must tell in favour of the tax payer'

VII. Other principles are:

There is no equity in taxation

Where the meaning of a statute is clearly expressed, the court will not have regard to any contrary intention or belief of parliament

Where the meaning of a statute is not clear, it should if possible, be construed so as to carry out the expressed or presumed intention of parliament.

Ambiguity may be resolved by subsequent legislation.

14 (2001) 17 NWLR (pt743) 706 at 756.

15 (1996) 8 NWLR (466) 256.

161921 I KB p 71.

1719411 ALL ER865 at $\mathrm{p} 868$. 


\section{E. TAX OFFENCES}

Tax offence is the violation of any law, regulation or legislation. Tax offences comprise of both civil and criminal vices under the Nigerian tax laws. The serious offences attract severe punishment while the mild offences attract less in form of fines in monetary terms. The Nigeria tax law empowers tax authority to use both civil as well as criminal sanctions to ensure and enforce tax compliance.

According to I. A. AYUA ${ }^{18}$, one of the greatest problems facing the country is the problem of Tax Avoidance and Evasion. Most if not all the offences under the Nigerian Tax law is one form of tax evasion or another.

Tax Evasion is the failure to pay ones tax or the reduce of one's liability; it is the unwillingness on the part of the tax payers to pay tax. Tax Evasion is definitively the illegal non-payment of tax. It is the unlawful attempt to minimise tax liability through the application of fraudulent schemes to dodge or frustrate tax laws.It is also interpreted to be an illegal practice wherein, aperson, organisation or corporation intentionally avoids paying his/ it's truetax liability. ${ }^{19}$

According to Lekan et $\mathrm{al}^{20}$, Tax is evaded through different methods amongst which are

I. Refusing to register with the relevant authority.

II. Failure to furnish a return, statement or information or keep records required.

III. Making an incorrect return by omitting or understanding any income liable to tax refusing or neglecting to pay tax.

IV. Over standing of expenses so as to reduce taxable profit or income which will also lead to payment of less than otherwise have been paid.

V. A tax payer hides away totalling without any tax returns at all.

Other forms of tax evasion according to Abdulrazaq ${ }^{21}$ are:

I. Failure to furnish a return statement or information or to keep record required as contained in PITA 1961.

II. Making an incorrect return by omitting or understanding any income liable to tax as contained in PITA 1961.

III. Giving any incorrect information in relation to any matter or thing affecting liability to tax as written in PITA 1961.

IV. Refusing or neglecting to pay as written in PITA 1961.

V. Corruption.

18 The Nigerian Tax law, lagos spectrum law series 1996 pg9.

19 Tax evasion. http://.www.businessdictionary.com/definition/tax-evasion.html. accessed 20/1/2019.

20 S.lekan\& O.Sunday, Taxation: principles and practice in Nigeria. 2006 pg 42.

21 Principles and practice of Nigerian Tax planning and management(1993) pg 3. 


\section{F. REASONS FOR TAX EVASION AND HOW JUSTIFIABLE IN LAW IS TAX EVASION IN NIGERIA ${ }^{22}$.}

I. Inequitable distribution of amenities: one of the essentials of a good tax system is, universality and equity whereby the tax should be all embracing without exceptions to individuals. Likewise, in the distribution of incentives to citizens, it is expected that government should be fair to all its citizens through the provisions of amenities and the good things of life.

II. There is no compensatory benefit as government have not been able to provide the citizens with(something of value) amenities commensurate with the taxes paid.

III. Misuse of taxes collected:most Nigerians would refrain from paying tax where it is evident that there is wastage of public funds by the government. Citizens would not want to pay or at most, pay under compulsion.

IV. Remoteness of Taxpayers to government: a typical Nigerian would where he thinks the government is not delivering as expected refuse to pay tax especially when imagined that his hard earned resources goes for their use.

V. Absence of spirit of civic responsibility.

VI. Loopholes in the tax law.

VII. No punishment for Evaders.

In a country like Nigeria, majority of companies as well as individuals are not willing to pay their taxes. Nigeria like other developing countries which needs to grow it's GDPA has a low GDP ratio ${ }^{23}$, due to tax criminality. Interestingly, both corporate and private individuals are culprits when it comes to the issue of non payment of tax. Tax evasion and avoidance has remained an impediment to national growth ${ }^{24}$ despite government effort the problem still lingers ${ }^{25}$. Evaders prefer to bribe officials rather than pay taxes, taxes paid are expected to end in private pockets not in public utilities. This attitude no doubt has eroded tax consciousness on the part of Nigerians and can in no way be justified because the effect of tax evasion is likely that,

I. There will be decrease in revenue

II. There will be inadequate supply of basic service for the welfare of the people like the provision of basic amenities for their comfort. In Lagos state for instance,it's revenue generation is impressive and development by the government is progressive when compared with other states.

22 Onuigo.O. 'Banking and Finance for Professional'. 1986.

23 S.M olokooba and R.Suliat. managing conflicts and other challenges of nationhood in Nigeria. Experimenting with Good Taxing system as a paraphernalia,A/HIKmah law journal 1(1) 2015,p.224.

24 Tax Evasion and Avoidance in nigeria. https://nialsng.wordpress.com/2015/05/13 tax=avoidance=nigeria/ accessed 4/3/2019.

25 Fatooki j.An Emperical Study of Tax Avoidance and Tax Evasion; A Critical issue in Nigerian Economic Development. Journal of Economics and sustainable Development(vol 5.No 18.2014) pg2. 
Tax offence which will attract prosecution is an offence in relation to taxation. Such an offence may be in the area of tax compliance, tax administrative vices or negligence on the part of the tax enforcement by tax authority. Both tax payers as well as tax authority can commit tax offence and such offence could attract prosecution by the judicial machineries which could lead to imprisonment if found guilty.

\section{TAX AVOIDANCE}

Interestingly, judicial approach to tax avoidance is at variance. Courts are not universally agreed on its legal consequences. Interestingly, some judges maintain that tax avoidance is not a moral breach of responsibility.

According to Ayua ${ }^{26}$, it is the arranging of one's affairs or structuring a transaction to reduce the tax liability which arises. In order word, tax avoidance is not considered an offence as one could get away with it by taking advantage of the law through what is called tax planning or tax holiday whereby a pioneering status is accorded an individual/company.

\section{G. DIFFERENT TYPES OF TAX INFRACTIONS}

Tax offences comprise of both civil and criminal vices under the Nigerian tax laws. The serious offences attract severe punishment while the mild offences attract less in form of fines in monetary terms. The Nigerian tax law empowers tax authority to use both civil as well as criminal sanctions to ensure and enforce tax compliance. ${ }^{27}$

Criminal sanctions in Nigeria are specific penalties of fine and imprisonment enforced by prosecution and it is classified into two category vis:

I. Sanctions within the Tax Acts

II. Sanctions outside of the Acts according to the general criminal law of the country as embodied in the penal code and criminal code.

Criminal penalties are applicable to offences under the following: ${ }^{28}$

I. Companies income Tax Act 2004 from sections 92- 99 CITA which includes:

1. penalty for offences for any person who is guilty of an offence against this Act or contravenes or fails to comply with any provisions of this Act which is $\mathrm{N} 20,000.00$. where the offence is the failure furnish a statement, information or keep records required, a further sum of N2,000.00 for each day.

2. False statements and returns. Any person, who aids, abets. Assist, for the purpose of obtaining a deduction or a set offshall be convicted to N1, 000.00 or imprisonment for five years or to both fine and imprisonment.

26 Ayua op cit.

27 M.T Abdulrazaq. Nigerian Tax offences and penalties $\mathrm{p} 19$.

28 Ibid. 
3. Penalties for offences by authorised and unauthorised persons are indicated for persons appointed for the due administration of such act or employed in connection with the assessment and collection of specified tax Acts.

4. Tax to be payable not withstanding proceedings for penalties Section.96 CITA

5. Prosecution to be with the sanction of the Board.

II. Federal Inland Revenue Service (Establishment Act, 2007).

1. Failure to deduct or remit tax: any person who being obliged to deduct any tax under this Act or the laws listed in the First Schedule to this Act, but fails to deduct, or having deducted, fails to pay for the Service within 30 days from the date the amount was deducted or the time the duty to deduct arose, commits an offence and shall, upon conviction, be liable to pay the tax withheld or not remitted per annum and interest at the prevailing Central Bank of Nigeria minimum rediscount rate and imprisonment fir period of not more than three years.

The Act shall also consider the following:

1. False declaration

2. Counterfeiting Documents, e.t.c.

3. Obstruction, e.t.c.

4. Penalties for offence by authorised and unauthorised persons.

5. Penalties where offenders are armed.

6. Unlawful assumption of character of an authorised officer.

III. Personal Income Tax Act, 2004.

1. A person guilty of an offence under this Act, or a person who contravenes or fails tocomply with any of the provisions of this Act or any rule or regulation made thereunder for which no other penalty is specifically provided, shall be liable on conviction to a fine of $\mathrm{N} 200$ and where the offence is the failure to furnish a return, statement or information or to keep records required, a further sum of forty nairafor every day during which the failure continues, and, in default payment, to imprisonment for six months, and the liability to such further sum shall commence from the day following the conviction, or from such other day thereafter as the Court may order.

2. Penalty for making incorrect returns.

3. False statements and returns.

4. Penalty for offences by authorised and unauthorised persons.

5. Tax to be payable not withstanding proceedings.

6. Prosecution to be with sanction of Board.

7. Saving for criminal proceedings.

IV. Petroleum Profits Tax Act, 2004.

1. Penalty for offences.

Any person guilty of an offence against this Act or of any rule madethereunder for which no other penalty is specifically provided, shall be liable to a fine, and where 
such offence is one under subsection (1) of section 24 of this Act, or is a failure to submit a return under section 33 of this Act or is a failure arising from the provisions of Part VI of this Act to deliver accounts, particulars or information or to keep records required, a further sum, for each and every day which such offence or failure continues, and in default of payment to imprisonment for six months, the liability for such further sum to commence from the day following the conviction, or from such day thereafter as the court may order.

2. Penalty for making incorrect accounts, e.t.c.

3. False statements and returns.

4. Penalty for failure to withhold tax.

5. Penalties for offences by authorised and unauthorised persons.

6. Deduction of tax at source.

7. Prosecution to be with the sanction of the Board.

8. Saving for criminal proceedings.

V. Value Added Tax Act 2004.

Furnishing of false document, e.t.c: any person who produces, furnishes or sends for the purpose of this Act or otherwise makes use for that purpose of a document which is false in any material particular or in furnishing an information to the Board, makes a statement which is false in any material particular, is guilty of an offence and liable on conviction to a fine of twice the amount under-declared.

The Act shall also consider the following:

1. Evasion of tax.

2. Failure to make attribution.

3. Failure to notify change of address.

4. Failure to issue tax invoice.

5. Resisting, e.t.c., an authorised officer.

6. Failure to keep proper records and accounts.

\section{H. INGREDIENT REQUIRED IN PROVING SUCH OFFENCES.}

The basic ingredient for tax evasion is mens rea and absence of any credible explanation for fraud, wilful default or neglect; that is the act itself and the guilty intent (mens rea) of the accused (now defendant). It is for the prosecution, i.e, the tax authority to prove that:

I. The evader knowingly made a false or deceptive statement in his return of income or that he wilfully evaded payment of taxes ${ }^{29}$. The burden may however change in certain circumstances where for instance, the plaintiff, in the absence of detailed information as to his annual income was assessed for tax by the defendant, the burden of proving that the assessment was on the plaintiff. 
II. Where a taxpayer is negligentwhich leads to a loss of taxes by accepting a wage below the standard of a reasonable person, he will be liable for negligent conduct which is civil in nature and the burden of proving such culpable conduct is on the State. But once the revenue (tax authority) establishes fraud or wilful default, the burden to show that the tax assessment is incorrect is imposed on the taxpayer.

Proof in criminal cases is beyond reasonable doubt while in civil cases before the tax authority is on the balance of probability.

III. The presumption of mens rea is essentially a problem of statutory interpretation in order to determine the guilty mind or intention as an essential element of the offence charged and as such, it is necessary to look at the object and terms of the law that creates that offence ${ }^{30}$.

In this new set up, the taxing statute will be a guide in the right direction. For instance, when Section 94 of CITA provides "any person, other than a company", makes it ambiguous if what it means is that offences listed under the section cannot be committed by a company yet, it so appears in the companies income tax Act? Office interchanged for person? Persons other than a company. A company cannot be sent to prison but can pay a fine.

\section{COURTS WITH JURISDICTION:TAX APPEAL TRIBUNAL (TAT) AND THE FEDERAL HIGH COURT (FHC)}

It is trite that the jurisdiction of a court or tribunal is derived from its enabling statute. It is the statute which create the court or tribunal that define it's jurisdiction. Jurisdiction is the authority which a court or tribunal has to decide matters which are litigated before it or to take cognisance of matters presented in a formal way before $\mathrm{it}^{31}$. The jurisdiction of a court to adjudicate in a dispute, civil or criminal is a sine qua non. Consequently, without the jurisdiction, a court or tribunal cannot make any valid order.

An effective mechanism for tax dispute resolution is also one of the features of a good tax system. Problem now arises in the tax appeal process whereby the tax appeal process is not easily accessible to tax payers neither are its processes and procedures simplified. The absence of certainty as regards the TAT and the Federal High Court as it relates to jurisdiction has thus become a clog in the wheel of progress in the attainment of justice over tax related matters in Nigeria.

The concerns around the jurisdiction of the TAT viz a viz the FHC has been resolved differently in two conflicting decisions of the $\mathrm{FHC}^{32}$. While one decision affirms the relevance and constitutional consistency of the TAT the other declares the TAT as unconstitutional. This is on the ground that s.251 (I a) of the constitution of the Federal Republic of

30 Ibid 95.

31 Cadbury Nig PLC v federal board of inland revenue (2009) 2 NWLR (Pt 1179) 561 at 576.

32 Http:?//www.vanguard.ngr.com/2017/04 appeal court-upholds-tax-appeal-tribunal-jurisdictiondetermine-disputes accessed 4/3/2019. 
Nigeria $^{33}$ provides that the FHC shall have exclusive jurisdiction to entertain matters between companies which relates to the revenue of the Federation. This decisions not persuaded by the history of the TAT, its transformation from the Body of the Appeal Commissioners (BAC) and the fact that it is a pre requisite to instituting an action before the FHC given that appeal from TAT goes to the FHC.

The TAT was Established in accordance with s 59(1) of the federal inland Revenue service(Establishment) Act 2007 (FIRS). The TAT formally took off pursuant to the Tax Appeal Tribunals Establishment order 2009 issued by the minister of finance, Federal Republic of Nigeria as published in the Federal Government Gazette No296, Vol 96 of 2 December 2009. By this Enactment TAT replaces the former body of Appeal Commissioners (BAC) and value Added Tax (VAT) Tribunals.

In the light of these conflicting decisions, it becomes imperative for the FIRS to consider alternative options to resolve these age-long disputes and collect the tax payments due to the Federation without delay. Thus, in the case of CNOOC Exploration \& production Nig Ltd \& Anor V Nigeria National petroleum Corporation \& Anor. ${ }^{34}$ The Court of Appeal has affirmed that the TAT has the jurisdiction to determine tax disputes and adjudicate over tax related matters. Accordingly, TAT adjudicates on all tax disputes arising from operations of the various Tax laws as spelt out in the fifth schedule to the FIRS Establishment in eight zones to cover the six geopolitical zones in Nigeria specifically, it is located in the following cities;

I. Abuja, Bauchi for the North West,

II. Plateau for the North Central,

III. Enugu for South East

IV. Ibadan for South West

V. Benin for South South

VI. Lagos for Lagos Inland and Lagos Mainland

The jurisdiction of the TAT is not at per with the FHC, they do not exercise coordinate jurisdiction. The TAT is primarily set up as an administrative court for speedy dispensation of tax matters to resolve disputes and controversies concerning

I. Corporation and individual income tax

II. Petroleum profit tax Act CAP:354 LFN 1990

III. VAT value Added tax No 102:1993

IV. Capital gains tax Act CAP 42 LFN 1990

V. Personal income tax Act No, 1041993

As an administrative body, it will be said with certainty that it lacks jurisdiction to try criminal offences under the Nigeria judicial system as was held in the case of Graba v univer-

331999 as amended.

34 (appeal Nos CA/L/1/1144/2015 and CA/L/1145/2015. 
sity of Maiduguri ${ }^{35}$ where the court held that, an administrative body lacks jurisdiction to try criminal offence. This then explains why in practice the criminal aspect of tax offence is referred to the FHC by the TAT for trial. In Seven Up Bottling co plc v Lagos state board of internal Revenue ${ }^{36}$ the Court of Appeal held that failure to remit tax deducted from salaries or emoluments of employees was a debt to the Lagos state board of internal revenue which is enforceable and recoverable in the court of law.

The TAT is constituted by five members headed by the chairman who must be a legal practitioner who has been so qualified to practice for a period of not less than 15 years with cognate experience in tax legislation and tax matters and four other members who will hold office for three years renewable for another three years if considered.

With the distinction in jurisdiction, the TAT is saddled with mainly civil cases and appeal lies to the FHC in criminal matters. If in the course of trial a matter is discovered to be criminal such matter will be referred to the FHC through the police or the appropriate prosecuting authority like the office of the attorney General state or federation for prosecution. However, parties could go directly to the FHC with criminal matters.

In the TAT the Appellant can file in a personal or representative capacity through his counsel and where the Appellant is not satisfied with the assessment, he raises an objection whereby the tribunal listens to the objection and decides to or not reduce the amount of the assessment raised then judgement is given. If not satisfied with the judgement, either party could appeal to the FHC. By s. 251(1) (a) 1999 constitution, it is now settled law that the FHC has exclusive jurisdiction over revenue matters to do with the government.

\section{J. DEFENCES.}

A person will not be held guilty of failure to pay tax unless the failure is wilful or with a guilty intent. He could be exonerated where there is no requisite mens rea to such offences which means that Tax payer's criminal liability is not absolute. Where a person pleads 'reasonable' cause or excuse as a defence to a charge of failure to discharge his statutory obligations under the Act.

I. Under the Nigerian Tax statutes, sufficient cause and reasonable excuse are possible defences. As to what constitute reasonable excuse, it was said by Abulrazaq ${ }^{37}$ that Where a person has a reasonable excuse for doing something required to be done, he is deemed not to have failed to do it within a reasonable time after the excuse had ceased. Sickness such as:

1. Coma.

2. Heart attack.

3. Stroke.

35 (1986) 1 NWLR PT 18 P. 550; Federal civil service v Laoye (1989) NWLR pt 106 p 652.

36 (1998) 7 NWLR pt 556 A 137.

37 Abdulrazaq op cit 101. 
Any serious mental or life threatening illness may be accepted as reasonable excuse only if the sickness engulfed the tax payer's time and attention during the period from the deadlines to the date the payment or completed return was sent in and steps had already been taken to have the payment or return ready on time.

II. Error as to date due to an erroneous recording of an extended date.(American milk products corp. v united states, $41 \mathrm{~F} 2 \mathrm{~d} 966 \mathrm{cf} . \mathrm{cl} .1$ 930)

III. Injunction.

\section{TAXATION IN THE UNITED STATE OF AMERICA (USA)}

The USA like Nigeria has separate Federal, State and Local governments with Taxes imposed at each of these levels. Taxes are levied on income, payroll, property, sales, capital gain, dividends, and imports estates. Apart from Eritrea, the united State taxes its non resident citizens in the same manner and rates as residents on worldwide income. Such imposition got the support of the Supreme Court as to its constitutionality in the case of cook v Tait ${ }^{38}$

Tax evasion in the USA $^{39}$ is illegal. By the tax code, 26 United States code, section 7201 provides for Attempt to evade or defeat tax as follows:

"any person who wilfully attempts in any manner to evade or defeat any tax imposed by this title or the payment thereof shall, in addition to other penalties provided by law, be guilty of a felony and, upon conviction thereof, shall be fined not more than $\$ 100,000$ (\$500,000 in the case of a corporation) or imprisoned not more than 5 years or both, together with the cost of prosecution"

To prove a violation of the statute, the IRS may carry out investigations to determine the correctness of tax return and collect necessary income tax, then, the prosecutor must show:

1. The existence of a tax deficiency (unpaid Federal tax)

2. An affirmative act constituting an evasion or attempted evasionof either the assessment or payment of that tax.

3. Wilfulness connoting the voluntary intentional violation of a known legal duty.

Compared with Nigeria, Americans pay their taxes fairly, honestly and on time and where there is a breach, prosecution is inevitable. For instance: when the famous Wesley Snipes ${ }^{40}$ avoided \$7 million in taxes from 1999 through 2001, the government was able to nab him and teach a lesson to tax protesters. In 2008, Snipe was convicted of three misdemeanour counts of failing to file tax returns, he was sentenced to three years and reported to the mckean Federal correctional institution, a medium security prison in Pennsylvania.

38 Taxation in the USA https://en.m.wikipedia.org accessed 1/5/2019.

39 HTTPS://EN.M.WIKIPEDIA.ORG/WIKI/TAXEVASION accessed 1/5/2019.

40 Forbes.com https://wwwgoogle.com accessed 1/5/2019. 
"Mike the situation" sorrentino ${ }^{41}$ pled guilty to tax evasion in 2018 and was sentenced to eight months in prison similarly, ja Rule ${ }^{42}$ and fat Joe ${ }^{43}$ were also sentenced to prison separately for failing to file tax returns. In addition, ja Rule was to pay $\$ 1.1$ million in back taxes and to remain on home confinement while fat Joe before his sentenced paid $\$ 718,000$ in back taxes according to the site.

Prosecution on tax evasion in the USA no doubt is so different from Nigeria particularly where tax offences are met with imprisonment. Prosecution in criminal offences in Nigeria is quite few and rarely ends with imprisonment. Theoretically, the laws are in place for proper prosecution but in reality and actual practice how many Nigerians have been visited with the full weight of these laws? Most often, criminal offences end up as being civil for claim of the sum and once the claim is met, proceedings terminate on the altar of civil litigation without recourse to the criminal aspect which in fact is an offence against the state and country. This, is food for thought!

\section{CHALLENGES}

I. Complexity of Tax Laws: Tax Laws in Nigeria are difficult for the common taxpayer to understand,and in some cases are problematic for even lawyers this is because lawyers do not have an orientation of the Taxation rules they still think the TAT like the normal court. The Tax Law is not simplified for the ordinary individual to read.

II. Public Enlightenment: People are not yet confident of the systems in the TAT and the Tax Laws. The government should explore ways of using the mass media to publicise such things as new tax laws, annual tax return obligations, the penalties for evasion, the enforcement activities which are conducted, the type of people who are caught trying to avoid their tax responsibilities.

III. Autonomy: the TAT is not an independent body, it is financially controlled by FIRS and the FIRS do bring their cases to the TAT, at the end they become the judge in their own case. The ministry of justice or the judiciary should fund the FIRS as the case may be. Likewise, the FIRS should be independent in order to be responsible to what they are suppose to do.

IV. Failure of the three tiers of government to provide social amenities affects tax compliance.

V. No knowledgeable personnel in the Tax system as it is a specialised skill.

VI. There is confusion in the relevant agencies to prosecute Tax matters. The statute did not spell out where the prosecutorial power lies.

VII. Legal disputes on the legality conflicting decisions of the Court of Appeal until that area is settled it cannot be said to be certain. The law itself has to be fine tuned to

41 Ibid.

42 Ibid.

43 Ibid. 
make the law very certain. Example is Lagos state where there are lots of matters between the government and the state over who to prosecute Tax matters.

VIII. Rules of the court in exercising the power of distraint to seal off government offices for not paying Tax is usually not obeyed.

\section{WAY FORWARD:}

I. Specialised courts should be created rather than going to the regular court like the FHC, specialised tax judges should mount those courts to adjudicate on tax matters promptly and efficiently to foster compliance and respect.

II. The TAT should be given a higher jurisdiction to be controlled by the High Court to handle both criminal and civil matters.

III. Tax Evasion should be criminally and promptly punished to serve as deterrence to defaulters. Defaulters must be adequately prosecuted for tax evasion, or the general public will not take taxation seriously and tax criminality will be on the increase.

IV. Monetary penalties and criminal sanctions should be drastically increased in order to make evasion of tax un worthwhile.

V. Tax officials, including prosecutors should be trained in criminal and civil procedures.

VI. The relevant tax Regulation laws in Nigeria should be expressed simply, clearly and intelligibly for easier understanding to all.

VII. Corruption as a problem must be addressed.

VIII. The blank power to compound any offence in Taxation by Tax authority should be removed. These will facilitate and ensure taking of tax matters to court for litigation and conviction when necessary.

\section{BIBLOGRAPHY/ REFERENCES:}

\section{BOOKS.}

Abdullahi Danjuma Zubairu: Understanding Nigerian Taxation; p1.

Abdulrazaq M.T: Principles and Practice in Nigerian Tax Planning and Management; 1993 p8.

Ayua.I.A: The Nigeria Tax Law; 1996 p9.

Dr Olateju Abiola Somorin; Teju Reference Book Nigerian Tax System General Accounting Taxation Terms; P2107.

M.T Abdulrazaq: Nigerian Tax Offences and Penalties;p 19.

Morse, G \& Williams, G Davies: Principles of Tax Law; 2004 p3.

Ola C.S:Income Tax Law and Practice in Nigeria; 2004 p8.

Onuigo.O. Banking and Finance for Professional 1986.

Osita Aguolu: Taxation and Tax Management in Nigeria; 2009 p4.

S. Lekan \& O Sunday: Taxation Principles and Practice in Nigeria; 2006 p42.

Stephen Ocheni: Principles and Practice of Taxation in Nigeria; 2010 p3. 


\section{JOURNALS.}

Fatok J.O.: An Emperical study of Tax Avoidance and Tax Evasion; A critical issue in Nigerian Economic Development. Journal of Economic and sustainable Development. (vol 5 No 18 2014) p 2.

S.M Olokooba and R.Suliat : Managing conflicts and other challenges of nationhood in Nigeria,experimenting with Good Taxing System as a paraphernalia, A/HIKmah Law journal 1(1)2015 p 224.

Sanni.A.S (1998) The approved list of Taxes. A commentary" Modern Practice journal of finance and investment law (2)2.

\section{INTERNET}

https://en:wikipedia.org/wiki/Tax investigationAccessed 1/5/2019.

http://.www.businessdictionary.com/definition/tax-evasion.html Accessed 20/1/2019.

https://nialsng.wordpress.com/2015/05/13tax=avoidance=nigeria Accessed 4/3/2019.

http:?//www.vanguard.ngr.com/2017/04appealcourt-upholds-tax-appeal-tribunal-jurisdiction-determine -dispute Accessed 4/3/2019.

Taxation in the USAhttps://en.m.wikipedia.orgAccessed1/5/2019.

https://en.m.wikipedia.org/wiki/taxevasion. Accessed 1/5/2019.

Forbes.comhttps://wwwgoogle.com Accessed 1/5/12019. 